\title{
PROFILE OF LACTOBACILLUS SPECIES IN CAMEL'S AND COW'S MILK
}

\author{
LAMIAA M. ALI ELSHREEF \\ Assiut Lab, Animal Health Research Institute \\ Email: lamiaa_arafat@yahoo.com
}

\section{ABSTRACT}

Received at: 23/9/2014

Accepted: 1/11/2014
A total number of 60 samples of camel's and cow's milk (30 samples of each) were investigated for the presence of Lactobacillus species in the present study. Enumerations of Lactobacilli in the examined camel's and cow's milk were carried out using usual media by the classic method (MRS media and broth). Typing of Lactobacilli strains isolated from the examined milk samples was determined by phenotypic characterization, growth at different temperatures and at different levels of salt and by the carbohydrates fermentation profile. The percentages of positive samples that contain Lactobacilli were 46.7 and $60 \%$ in camel's and cow's milk samples respectively, and its total counts ranged from $37 \times 10^{3}$ to $43 \times 10^{5} \mathrm{cfu} / \mathrm{ml}$ with an average of $12 \times 10^{5} \mathrm{cfu} / \mathrm{ml}$ in camel's milk and ranged from $5 \times 10^{3}$ to $28 \times 10^{5}$ with an average of $5 \times 10^{5} \mathrm{cfu} / \mathrm{ml}$ in cow's milk. Three types of Lactobacillus species were recovered from camel's milk samples $(L$. bulgaricus detected in $23.3 \%$, L. planetarium detected in $13.3 \%$ and L. casei detected in $10 \%$ of the examined camel's milk samples). On the other hand only two species were detected in cow's milk (L. bulgaricus detected in $20 \%$ and $L$ acidophilus detected in $40 \%$ of the examined cow's samples). It could be concluded that Lactobacillus bulgaricus, Lactobacillus plantarum, and Lactobacillus casei which are detected in camel's milk and Lactobacillus bulgaricus and Lactobacillus acidophilus which are isolated from cow's milk could be used in the development of starter cultures for the production of fermented camel and cow's milk. However, further research works are needed to evaluate the performance of these isolates especially if it is used as mixed starter cultures.

Key words: Lactobacillus, camel's milk, cow's milk.

\section{INTRODUCTION}

Lactic acid bacteria ( $\mathrm{LAB})$ have a long history of application in fermented foods because of their beneficial influence on nutritional, organoleptic, and shelf-life characteristics. They cause rapid acidification of the raw material through the production of organic acids, ethanol, aroma compounds, bacteriocins, exopolysaccharides and several enzymes of importance (Luc and Fre'de'ric, 2007). They have long been consumed by people in several fermented foods such as dairy products. Today, LAB are a focus of article in press intensive international research for their essential role in most fermented food, for their ability to produce various antimicrobial compounds promoting probiotic properties (Temmerman et al., 2002) including antitumor activity (DeVuyst and Dege-est, 1999 and Hilde et al., 2003), reduction of serum cholesterol (Desmazeaud, 1996 and Jackson et al., 2002), alleviation of lactose intolerance (De'Vrese et al., 2001), stimulation of the immune system (Isolauri et al., 2001) and stabilization of gut micro-flora (Gibson et al., 1997).

LAB strains that produce exopolysaccharide are employed in the manufacture of fermented milk to improve its texture and viscosity (Curk et al., 1996 and Ruas-Madiedo et al., 2002). Some LAB strains are known to produce mannitol which is claimed to have several health promoting effects (Wood and Holz-apfel, 1995 and Wisselink et al., 2002). New sources of nutrients should be more exploited for varying the human diet and also to benefit from new functional ingredients and natural food components.

Camel milk is nutritionally and medicinally superior to cow milk and milk from other species. It is used therapeutically against jaundice, problems of spleen, T.B., anemia and piles (Rao et al., 1970 and Khalid et al., 2012). When camel milk is left to stand, its 
acidity rapidly increases due to presence of LAB (Ohris and Joshi, 1961, Ahmed and Kanwal, 2004). Lactobacillus salivarius, Lactobacillus casei and Lactobacillus plantarum were the common LAB recovered from camel's milk (Khedid et al., 2009 and Seifu et al., 2012). Growth of L. acidophilus is supported by camel milk so it grows more rapidly in camel milk than others. L. acidophilus converted 56 and $74 \%$ of lactose into lactic acid. Strains isolated from camel milk were best for acid production and coagulated the milk in less time, so better results can be obtained by coagulating milk with starter culture prepared from strains isolated from camel milk (Ahmed and Kanwal, 2004).

Lactobacilli are known to produce many types of bacteriocins like acidophilin, acidolin, lactocidin, bulgarican, lactolin, lactobacillin and lactobrevin (Alvarez-Olmos and Oberhelman, 2001). The functional properties and safety of probiotics of particular strains of $L$. casei, L. lactis and L. acidophilus from various sources have been extensively studied and proved to be efficient for prevention of infectious diseases (Halami et al., 1999). L. rhamnosus and L. plantarum had strongest antagonistic potential against Salmonella typhi followed by Proteus vulgaris and Klebsiella pneumonia (Tambekar and Bhutada, 2010).

Lactobacillus spp. is used to treat antibiotic diarrhea, yeast infection and urinary tract infection. It was studied for its possible benefit in protection against colon cancer and the adverse effects of chemotherapy and radiotherapy. Also some strains of L. caseii are known to have anti-inflammatory effects and offer immune support enhancing the body defense against diseases (Sara, 2010).

African and Arab countries, where the breeding conditions for cows are severe and fastidious, can get over this situation by developing a breeding system for local animals such as camel. The beneficial microbiota of camel milk represented by LAB is a potential source of biological materials to be used in dairy technology. The transformation of camel milk by fermentation is not easy and more research for elucidating the process is needed. Cow's milk was widely investigated, up until now, little studies were undertaken on the camel's milk to characterize its microflora especially LAB. Thus, this study aims: 1- Isolation and characterization of lactobacillus bacteria from the raw camel's and cow's milk produced in Assiut and NewVally Governorates, Egypt. 2- Comparing the total count, percentage and different types of lactobacilli recovered from examined milk samples of both species.

\section{MATERIALS and METHODS}

Sampling: A total number of 60 samples of camel's and cow's milk (30 samples of each) were collected from different regions at Assiut and Newvally Governorates. Samples were immediately cooled and transported to the laboratory in an icebox $\left(4{ }^{\circ} \mathrm{C}\right)$ and investigated for the content of Lactobacilli on the arrival.

Isolation and enumeration of Lactobacilli: Ten (10) $\mathrm{ml}$ of milk sample were homogenized with $90 \mathrm{ml}$ of sterile saline solution to make an initial dilution $\left(10^{-1}\right)$. The suspension was used for making suitable serial dilutions up to $10^{-5}$ by incorporating $1 \mathrm{ml}$ into 9 $\mathrm{ml}$ of sterile saline solution in sterile tubes.

Enumeration of Lactobacilli was determined using the elective media, DeMan, Rogosa and Sharpe (MRS) agar (CMO 361 Oxoid England) according to DeMan et al. (1960). 15-20 ml sterile MRS agar (45$50{ }^{\circ} \mathrm{C}$ ) was poured into sterile petri dishes containing $1 \mathrm{ml}$ of diluted test sample. The inoculums distributed throughout the medium by gentle rotation of plates in one direction and then in the reverse direction. The inoculated plates were left for 5 -10 minutes to solidify, and then incubated at $37{ }^{\circ} \mathrm{C}$ for $48-72$ hours in $\mathrm{CO}_{2}$ Incubator. Lactobacilli colonies are smooth, white and convex with regular edges. After incubation, colonies were enumerated and recorded as colony forming units (cfu) per milliliter of milk.

The colonies were randomly picked from plates and transferred in $10 \mathrm{ml}$ of appropriate MRS broth. The selected colonies were purified by repeated streaking on the appropriate agar media. Lactobacilli strains were kept on MRS agar slant at $4{ }^{\circ} \mathrm{C}$ and streaked every 4 weeks. Prior to use, Lactobacilli strains were activated in MRS broth at $30{ }^{\circ} \mathrm{C}$ for $24 \mathrm{hrs}$, and subculture in MRS agar at $30{ }^{\circ} \mathrm{C}$ for $24 \mathrm{hrs}$. Gram staining, catalase reaction, gas production, growth at different temperatures and growth at different sodium chloride concentrations were tested for a preliminary separation of different isolates of lactobacilli. Biochemical identification (Lactose, sucrose, mannitol, xylose, maltose and trehaloze fermentation as well as production of $\mathrm{NH}_{3}$ from arginine) was then conducted.

Lactobacilli strains were characterized according to methods recommended by several authors (Harrigan and McCance, 1976; Sharpe, 1979; Schleifer et al., 1985; Kandler and Weiss, 1986; Schleifer and Kilpper-Ba“1z, 1987; Facklam and Collins, 1989; Curk et al., 1996; Charteris et al., 2001; Klein, 2001, Ahmed and Kanwal, 2004 and Khedid et al., 2009). 
Table 1: Biochemical characteristics distinguishing species of the genus lactobacilli (Peter et al,, 1986).

\begin{tabular}{|c|c|c|c|c|c|c|c|c|c|c|c|}
\hline \multirow{2}{*}{$\begin{array}{c}\text { Lactobacilli } \\
\text { Spp. }\end{array}$} & \multicolumn{3}{|c|}{ Growth temp. } & \multicolumn{6}{|c|}{ Sugar fermentation } & \multirow{2}{*}{$\begin{array}{c}\mathrm{NH}_{3} \\
\text { From } \\
\text { arginine }\end{array}$} & \multirow{2}{*}{$\begin{array}{r}\text { Growth } \\
\text { in } 4 \% \\
\mathrm{NaCl} \\
\text { broth }\end{array}$} \\
\hline & $15^{\circ} \mathrm{C}$ & $37^{\circ} \mathrm{C}$ & $45^{\circ} \mathrm{C}$ & lactose & sucrose & mannitol & xylose & maltose & trehaloze & & \\
\hline L .plantarum & + & - & $\mathrm{V}$ & + & + & + & - & + & + & - & + \\
\hline $\mathrm{L}$.brevis & + & + & - & $+/-$ & + & $+/-$ & + & + & - & + & + \\
\hline L .bultgaricus & - & + & + & + & - & - & - & - & - & - & - \\
\hline L casei. & + & - & $\mathrm{V}$ & $+/-$ & $+/-$ & + & - & + & + & - & + \\
\hline L .leichmanii & - & - & + & $+/-$ & + & - & - & - & - & $+/-$ & - \\
\hline L. delbruckii & - & - & + & - & + & - & - & $+/-$ & $+/-$ & - & - \\
\hline L. acidophilus & - & + & + & + & + & - & - & + & $+/-$ & $+/-$ & - \\
\hline L fermenti. & - & + & + & + & $+/-$ & - & $+/-$ & + & $+/-$ & + & - \\
\hline +: positive & & & Tegat & & $\mathrm{V}:$ Var & & +/-: So & strains & ve positiv & or negative & \\
\hline
\end{tabular}

\section{RESULTS}

The percentage and total count counts of isolated Lactobacilli in the examined raw camel's and cow's milk are shown in Tables 2 and 3. Types and incidence of the isolated Lactobacilli spp. that recovered from positive camel's and cow's milk samples are presented in Tables, 4 and 5.

Table 2: Prevalence of Lactobacilli isolated from the raw camel's and cow's milk.

\begin{tabular}{lccc} 
& & \multicolumn{2}{c}{ Positive samples } \\
Type of sample & $\begin{array}{c}\text { Number of examined } \\
\text { samples }\end{array}$ & Number & $\%$ \\
\cline { 3 - 4 } & 30 & 14 & 46.7 \\
\hline Camel's milk & 30 & 18 & 60 \\
\hline
\end{tabular}

Table 3: Total counts of isolated Lactobacilli in the examined raw camel's and cow's milk

\begin{tabular}{cccc}
\hline \multirow{2}{*}{ Milk samples } & \multicolumn{3}{c}{ Examined samples } \\
\cline { 2 - 4 } & \multicolumn{3}{c}{ Total counts $(\mathbf{c f u}) / \mathrm{ml}^{3}$} \\
\cline { 2 - 4 } & Min. & Max. & Average \\
\hline $\begin{array}{c}\text { Camel's milk } \\
\text { ( No.: 30) }\end{array}$ & $37 \times 10^{3}$ & $43 \times 10^{5}$ & $12 \times 10^{5}$ \\
\hline $\begin{array}{c}\text { Cow's milk } \\
\text { ( No.: 30) }\end{array}$ & $5 \times 10^{3}$ & $28 \times 10^{5}$ & $5 \times 10^{5}$ \\
\hline
\end{tabular}

Table 4: Types and incidence of the isolated Lactobacilli spp. that recovered from positive camel's milk samples.

\begin{tabular}{lccccc}
\hline Lactobacillus spp. & No, & $\%$ & Min. & Max. & Average \\
\hline L. bulgaricus & 7 & 23.3 & $37 \times 10^{3}$ & $12 \times 10^{5}$ & $11.4 \times 10^{5}$ \\
\hline L plantarium. & 4 & 13.3 & $11 \times 10^{5}$ & $43 \times 10^{5}$ & $19 \times 10^{5}$ \\
\hline L.casei & 3 & 10 & $93 \times 10^{3}$ & $6 \times 10^{5}$ & $3.8 \times 10^{5}$ \\
\hline
\end{tabular}

No.: Number of positive milk samples.

Percentages calculated according to the No. of total milk samples of each animal species. 
Assiut Vet. Med. J. Vol. 60 No. 143 October 2014

Table 5: Types and incidence of the isolated Lactobacilli spp. that recovered from positive cow's milk samples.

\begin{tabular}{lccllc}
\hline Lactobacillus spp. & No, & $\%$ & Min. & Max. & Average \\
\hline L. bulgaricus & 6 & 20 & $27 \times 10^{3}$ & $28 \times 10^{5}$ & $8 \times 10^{5}$ \\
\hline Lacidophilus & 12 & 40 & $5 \times 10^{3}$ & $13 \times 10^{5}$ & $3.5 \times 10^{5}$ \\
\hline
\end{tabular}

No.: Number of positive milk samples. Percentages calculated according to the No. of total milk samples of each animal species.

\section{DISCUSSION}

Lactobacillus spp. were isolated from camel's and cow's milk and identified. Up to now, camel's milk produced in Egypt was not deeply investigated for the characterization of the microflora. The isolated strains were investigated to retrieve the number of species and varieties of the different genera. Tests were repeated two times to avoid confusing results in the identification.

In the present study the percentages of positive samples that contain Lactobacilli were 46.7 and $60 \%$ in camel's and cow's milk samples respectively (Table, 2). The obtained results of Lactobacilli counts revealed that it ranged from $37 \times 10^{3}$ to $43 \times 10^{5} \mathrm{cfu} / \mathrm{ml}$ with an average of $12 \times 10^{5} \mathrm{cfu} / \mathrm{ml}$ in camel's milk samples and ranged from $5 \times 10^{3}$ to $28 \times 10^{5}$ with an average of $5 \times 10^{5} \mathrm{cfu} / \mathrm{ml}$ in cow's milk samples (Table, 3 ). These results indicated that the percentage of positive samples that contain Lactobacilli were higher in cow's milk than that of camel's milk, in contrary to the total count, which was higher in camel's milk than that of cow's milk. Khedid et al. (2009) isolated lactobacilli in in camel's milk samples in Morocco with levels varied from $2.5 \times 10^{2}$ to $6 \times 10^{7}$ $\mathrm{cfu} / \mathrm{ml}$ with an average of $7.5 \times 10^{6} \mathrm{cfu} / \mathrm{ml}$. Aziz et al. (2009) identified, Lactobacillus bulgaricus in $28 \%$ of examined cow milk samples. Fatechenti et al. (1979), Tornadijo et al. (1995) and Badis et al. (2004) reported that Lactobacilli counts found in camel milk were higher compared to that reported in other types of milk such as goat's milk. However, similar counts recorded in this study were reported in ewe's milk (Devoyod et al., 1968; Fernandez del Pozo et al., 1988; Poullet et al., 1991).

Typing of Lactobacilli strains isolated from camel's and cow's milk samples was determined by phenotypic characterization, growth at different temperatures and at different levels of salt and by the carbohydrates fermentation profile (Table, 1). Three types of Lactobacillus species were recovered from camel's milk samples. 1. L. bulgaricus detected in $23.3 \%$ of the examined camel's samples with total counts ranged from $37 \times 10^{3}$ to $12 \times 10^{5}$ and an average of $11.4 \times 10^{5} \mathrm{cfu} / \mathrm{ml}$. 2. L. planetarium detected in 13.3 $\%$ of the examined camel's samples with total counts ranged from $11 \times 10^{5}$ to $43 \times 10^{5}$ and an average of
$19 \times 10^{5} \mathrm{cfu} / \mathrm{ml}$ and 3. L. casei detected in $10 \%$ of the examined camel's samples with total counts ranged from $93 \times 10^{3}$ to $6 \times 10^{5}$ and an average of $3.8 \times 10^{5}$ $\mathrm{cfu} / \mathrm{ml}$ (table, 4).

On the other hand only two species were detected in cow's milk, L. bulgaricus detected in $20 \%$ of the examined cow's samples with total counts ranged from $27 \times 10^{3}$ to $28 \times 10^{5}$ and an average of $8 \times 10^{5}$ $\mathrm{cfu} / \mathrm{ml}$ and $L$ acidophilus detected in $40 \%$ of the examined cow's samples with total counts ranged from $5 \times 10^{3}$ to $13 \times 10^{5}$ and an average of $3.5 \times 10^{5}$ $\mathrm{cfu} / \mathrm{ml}$ (table, 5). Khedid et al. (2009) reported that lactic acid bacteria species, frequency Lactobacillus are present in camel's milk, the authors' isolated Lactobacillus casei and Lactobacillus plantarum from camel's milk in similar proportion.

This group is best known as starter for fermented dairy products because of the following criteria: production of large amounts of acid in milk, synthesis of vitamin (Forsse'n et al., 2000), flavor compounds, production of folic acid and production of EPS that has an effect on the rheological properties of yoghurt. The mesophilic homofermentative lactobacilli represented by Lactobacillus casei, and Lactobacillus plantarum has been reported that they are usually found in cheese (Devoyod and Mu“1ler, 1969). Strains of this group can be used to adjunct starter culture to accelerate ripening and to produce desirable flavors and to eliminate defects by adventitious nonstarter LAB (NSLAB) since they inhibit their outgrowth. Herreros et al. (2003) showed that some strains of Lactobacillus casei subsp. casei were developing acid activity as rapidly as some lactococci, the authors explained that lactobacilli metabolize lactose more slowly than lactococci but the final acid production can be similar to or even higher than lactococci.

It could be concluded that in the present study, Lactobacillus bulgaricus, Lactobacillus plantarum, and Lactobacillus casei were the detected Lactobacillus bacteria in camel's milk while Lactobacillus bulgaricus and Lactobacillus acidophilus were the Lactobacillus bacteria in cow's milk. More studies are needed to complete the isolation and the characterization of Lactobacillus strains that could be present in camel milk. These isolates from the present study could be used in the 
development of starter cultures for the production of fermented camel milk under controlled environment in the future. However, further research work is needed to evaluate the performance of these isolates when used especially if it is used as mixed cultures.

\section{REFERENCES}

Ahmed, T. and Kanwal. R. (2004): Biochemical characteristics of lactic acid producing bacteria and preparation of camel milk cheese by using starter culture. Pakistan Vet. J., 24 (2): 87-91.

Alvarez-Olmos, M.I. and Oberhelman, R.A. (2001): Probiotic agents and infectious diseases: a modern perspective on a traditional therapy. Clin Infectious Diseases, 32 (11): 1567-1576.

Aziz, T.; Khan, H. and Bakhtair, S.M. (2009): Incidence and relative abundance of lactic acid bacteria in raw milk of buffalo, cow and sheep. Journal of Animal \& Plant Sciences, 19 (4): 168-173.

Badis, A.; Gue tarni, D.; Moussa-Boudjema, B.; Henni, D.E.; Tornadijo, M.E. and Kihal, M. (2004): Identification and technological properties of lactic acid bacteria isolated from raw goat's milk of four Algerian races. Food Microbiol. 2, 579-588.

Charteris, W.P.; Kelly, P.M.; Morelli, L. and Collins, J.K. (2001): Quality control Lactobacillus isolates for use with the API50 $\mathrm{CH}$ and API ZYM systems at 371C. J. Basic Microbiol. 41, 241-251.

Curk, M.C.; Hubert, J.C. and Bringel, F. (1996): Lactobacillus paraplantarum sp. Nov., a new species related to Lactobacillus plantarum. Int. J. Syst. Bacteriol. 46, 595-598.

DeMan, J.D.; Rogosa, M.A. and Sharp, M.E. (1960): Amedium for the cultivation of Lactobacilli. J. Appl. Bact., 23: 130-135.

Desmazeaud, M. (1996): Les bacte'ries lactiques dans l'alimentation humaine: Utilisation et innocuite'. Cahiers Agric. 5, 331-343.

Devoyod, J.J.; Bret, G. and Auclair, J.E. (1968): La flore microbienne du fromage de Roquefort. Son e'volution au cours de la fabrication et de l'affinage du fromage. Le Lait 48, 613-629.

Devoyod, J.J. and Mu“ller, M. (1969): Microbiological flora of Roqueforti cheese. III. Lactic streptococci and leuconostocs. Influence of various contaminating microorganisms. Le Lait 49, 369-399.

De'Vrese, M.; Steglman, A.; Richter, B.; Fenselau, S.; Laue, C. and Scherezenmeir, J. (2001): Probiotics-com-pensation for lactase insufficiency. Am. J. Clin. Nutr. 73, 421-429.

DeVuyst, L. and Dege-est, B. (1999): Heteropolysaccharides from lactic acid bacteria. FEMS Microbiol. Rev. 23, 130-135.

Facklam, R.R. and Collins, M.D. (1989): Identification of Enterococcus species isolated from human infections by a conventional test scheme. J. Clin. Microbiol. 27, 731-734.

Fatechenti, F.; Deiana, P.; Farris, G.A. and Soggia, G. (1979): Etudes microbiologiques sur le lait et le fromage deche 'vre en Sardaigne. Note II: Streptocoques, Lactobacilles et Leuconostocs. Le Lait 59, 387-400.

Fernandez del Pozo, B.; Gaya, P.; Medina, M.A.; Rodriguez-Martin, M.A. and Nunez, M. (1988): Changes in the microflora of la serra ewe's milk cheese during ripenning. J. Dairy Res. 55, 449-455.

Forsse'n, K.M.; Ja "gestard, M.I.; Wigert,, K. and Wittho"ft, C.M. (2000): Folates and dairy products: a critical update. J. Am. Coll. Nutr. 19, 100-110.

Gibson, G.R.; Saveedra, J.M.; Mac Farlane, S. and Mac Farlane, G.T. (1997): Probiotics and intestinal infections. In: Fuller, R. (Ed.), Probiotic. 2: Applications and Practical Aspects. Chapman \& Hall, New York, pp. 10-39.

Halami, P.M; Chandrashekar, A. and Joseph, R. (1999): Characterization of bacteriocinogenic strains of lactic acid bacteria in fowl and fish intestines and mushroom. Food Biotechnol, 13(2): 121-136.

Harrigan, W.F. and McCance, M.E. (1976): Laboratory Methods in Food and Dairy Microbiology, second ed. Academic Press, London.

Herreros, M.A.; Fresno, J.M.; Gonzalez, M.E. and Tornadijo, $\quad$ P. (2003): Technological characterization of lactic acid bacteria isolated from Armada cheese (a Spanish goat's milk cheese). Int. Dairy J. 13, 469-479.

Hilde, M.; Ostile Merete Helland, H. and Judith Narvhus, A. (2003): Growth and metabolism of selected strains of probiotic bacteria in milk. Int. J. Food Microbiol. 87, 17-27.

Isolauri, E.; Su "tas, Y.; Kankaapa“a ;, P.; Arvilommi, H. and Salminen, S. (2001): Probiotics: effects of immunity. Am. J. Clin. Nutr. 73: 444-450.

Jackson, M.S.; Bird, A.R. and Mc Orist, A.I. (2002): Compar-ison of two selective media for the detection and enumeration of lactobacilli in human faeces. J. Microbiol. Methods 51, 313-321.

Kandler, O. and Weiss, N. (1986): Genus Lactobacillus Beijerinck 1901, 212 AL. In: Sneath, P.H.A., Mair, N.S.

Khalid, G.A.; Alyaa, M.; Mohammed, A.A. and Murtda, H.H. (2012): The Role of Camel's Milk against Some Oxidant-Antioxidant Markers of Male Rats Treated With CCl4. International Journal of Research in Pharmaceutical and Biomedical Sciences. 3 (1): 385 -389.

Khedid, K.; Faid, M.; Mokhtar, A. and Soulayman A. Zinedine. (2009): Characteristics of lactic acid 
bacteria isolated from the one humped camel milk produced in Morocco. Microbiological Research164: 81-91.

Klein, G. (2001): International Committee of Systematic Bacteriology, subcommittee on the taxonomy of bifidobacterium,lactobacillus and related organisms. Minutes of the meeting. Int. J. Syst. Evol. Microbiol. 51: 259-261.

Luc, D. and Fre'de'ric, L. (2007): Bacteriocins from Lactic acid bacteria: Production, purefecation and food Application. J. Mol. Micobiol., 13. 194-199.

Ohris, S.P. and Joshi, B.K. (1961): Composition of camel milk. Indian Vet. J., 38: 514-516.

Peter, H.A.; Nicholas, S.M.; Elisabeth, M.S. and John, G.H. (1986): Bergey's Manual of Systemic Bacteriology, Volume 2, lactobacilli and bifidobacteria.

Poullet, B.; Huertas, M.; Sanchez, A.; Caceres, P. and Larriba, G. (1991): Microbial study of casar de caceres cheese throughout ripening. J. Dairy Res. 58, 231-238.

Rao, M.B.; Jupta, R.C. and Dastur, N.N. (1970): Camels milk and milk products. Ind. J. Dairy Sci., 23:71-78.

Ruas-Madiedo, P.; Tuinier, R.; Kanning, M. and Zoon, P. (2002): Role of exopolysaccharides produced byLactococcus lactis subsp. cremorison the viscosity of fermented milks. Int. Dairy J. 12: 689-695.

Sara, T. (2010): Types of probiotics. ContrributingWriter. SaraTommm.com

Schleifer, K.H.; Kraus, J.; Dvorak, C.; Kilpper-Ba lz.R.; Collins, M.D. and Fischer, W. (1985):

Transfer of Streptococcus lactis and related Streptococci to the genus.

Schleifer, K.H. and Kilpper-Ba lz.R. (1987): Molecular and chemotaxonomic approaches to the classification of streptococci, enterococci and lactococci. Syst. Appl. Microbiol. 10: 1-19.

Sharpe, M.E. (1979): Identification of the lactic acid bacteria. In: Skinner, F.A., Lovelock, D.W. (Eds.), Identification Methods for Microbiologist. Academic Press, London: 233-259.

Seifu, E.; Araya, A.; Kurtu1, M.Y. and Yilma, Z. (2012): Isolation and characterization of lactic acid bacteria from Ititu: Ethiopian traditional fermented camel milk. Journal of Camelid Science, 5: 82-98.

Tambekar, D.H. and Bhutada, S.A. (2010): An evaluation of probiotic potential of lactobacillus sp. from milk of domestic animals and commercial available probiotic preparations in prevention of enteric bacterial infections. Recent Research in Science and Technology, 2(10): 82-88.

Temmerman, R.; Pot, B.; Huys, G. and Swings, J. (2002): Identification and antibiotic susceptibility of bacterial isolates from probiotic products. Int. J. Food Micro-biol. 81: $1-10$.

Tornadijo, M.E.; Fresno, J.M.; Bernardo, A.; Martin Sarmiento, R. and Carballo, J. (1995): Microbiological changes throughout the manufacturing and ripening of Spanish goat's raw milk cheese (Armada Variety). Le Lait 75: 551-570.

Wisselink, H.W.; Weusthuis, R.A.; Eggink, G.; Hugen-holtz, J. and Grobben, G.J. (2002): Mannitol production by lactic acid bacteria: a review. Int. Dairy J. 12:151-161.

Wood, B.J.B. and Holz-apfel, W.H. (1995): The Genera of Lactic Acid Bacteria, vol. 2. Aspen Publishers, Gaithersburg, MD.

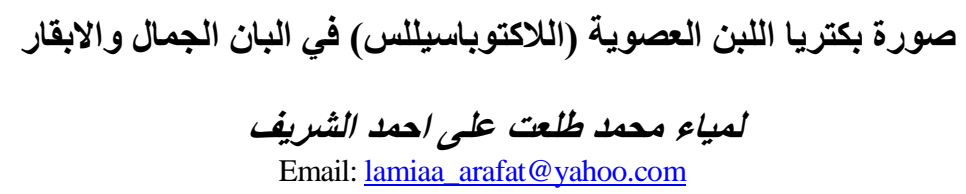

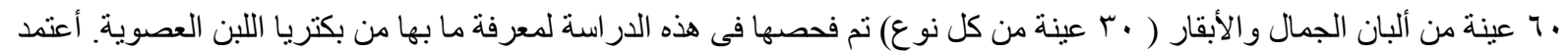

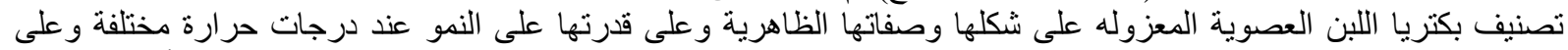

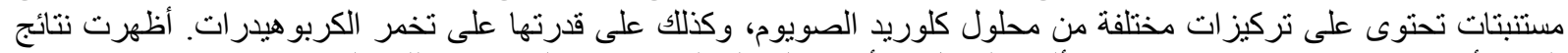

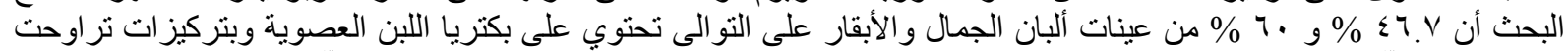

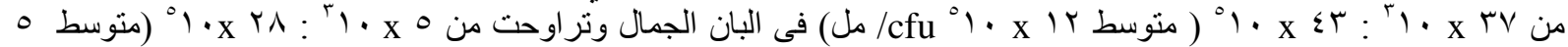

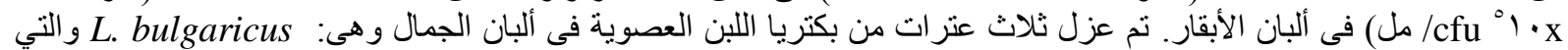

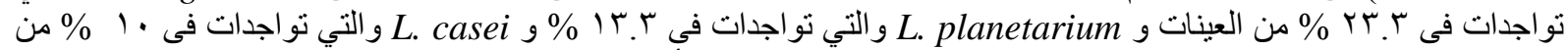

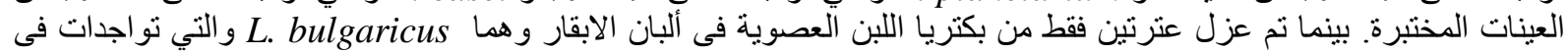

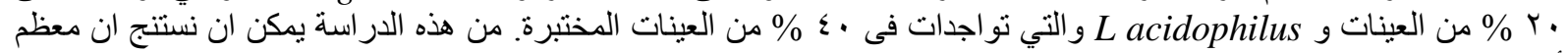

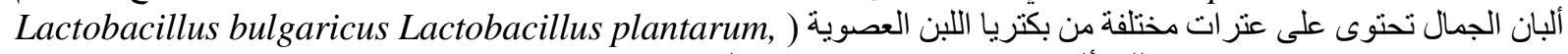
(Lactobacillus bulgaricus and وكذلك ألبان الابقار تحتوى ايضا على سلالات اخلى (Lactobacillus casei ، ( Lactobacillus acidophilus) تفيد فى تصنيع منتجات البان الجمال و الابقار. 